\title{
The Development of the Burial Mound Tradition in the Caddo Area
}

Frank F. Schambach

Unknown

Follow this and additional works at: https://scholarworks.sfasu.edu/ita

Part of the American Material Culture Commons, Archaeological Anthropology Commons, Environmental Studies Commons, Other American Studies Commons, Other Arts and Humanities Commons, Other History of Art, Architecture, and Archaeology Commons, and the United States History Commons

Tell us how this article helped you.

This Article is brought to you for free and open access by the Center for Regional Heritage Research at SFA ScholarWorks. It has been accepted for inclusion in Index of Texas Archaeology: Open Access Gray Literature from the Lone Star State by an authorized editor of SFA ScholarWorks. For more information, please contact cdsscholarworks@sfasu.edu. 


\section{The Development of the Burial Mound Tradition in the Caddo Area}

Creative Commons License

(c) (i) (8)

This work is licensed under a Creative Commons Attribution-NonCommercial 4.0 International License 


\title{
THE DEVELOPMENT OF THE BURIAL MOUND TRADITION
}

\author{
IN THE CADDO AREA
}

\author{
Frank F. Schambach
}

\section{Introduction}

This is a significantly revised version of a paper 1 presented at the 1994 East Texas Archeological Conference in Tyler, Texas. The gist of that paper was that the origins of the burial mound tradition ${ }^{1}$ in the Caddo area can be traced, not to the Coles Creek culture in the Lower Mississippi Valley as the conventional wisdom would have it (see, for example, Webb and McKinney 1975:119-120; see also Schambach 1982:190, 1991), but to an independent Fourche Maline mound building tradition that developed in and around the Red River Valley beginning about 100 B.C. ${ }^{2}$ I still think that there was an independent Fourche Maline mound building tradition and I still think that, as I tried to show in my conference presentation, the earliest mounds at the earliest Caddo ceremonial center we know of, Mounds D and C at the Crenshaw site, were constructed in that tradition. As I will show in this paper, it is clear that the Crenshaw mounds were not "Coles Creek" mounds.

But in the three years since my conference presentation, 1 have changed my interpretation of the slightly later, late Fourche Maline period, full-fleshed, group burials that were also found in Mound $\mathrm{C}$ at Crenshaw. These are the earliest graves found so far at any Caddo site that secm to be clearly in the tradition of the distinctive, high status "shaft tomb" burials of early Caddo culture in the Red River Valley. In my original presentation 1 argued that these graves, and hence the early Caddo mound burial tradition, could be derived from the old Fourche Maline burial mound tradition. But since then 1 have come to consider that argument unconvincing and untenable.

The new argument l offer here is that the stimulus for the early Caddo mound burial pattern did indeed come from outside the Caddo Area, as many archeologists have suggested, but it was not from Coles Creek culture as has commonly been supposed. I now think that these graves indicate the point in time when powerful influences from the "Emergent Mississippian" cultures to the northeast of the Caddo Area, perhaps from Cahokia itself, were beginning to transform the centuries-old Fourche Maline burial mound tradition into the essentially Mississippian early Caddo burial mound tradition. This transition must have entailed not just changes in the Fourche Maline burial mound tradition but also basic changes in the structure and importance of the elite stratum, if such there was, in Fourche Maline society itself. Thus, these graves would reflect an early stage in the transformation, under Emergent Mississippian influence, of the evidently still quite weakly developed elite social stratum in late Fourche Maline society into the well defined elite stratum that seems to have dominated early Caddo society; i.e., the social elite responsible for the deep, richly accoutered shaft tombs that were emplaced in mounds at all the important early Caddo ceremonial centers.

So in this paper I will first attempt to isolate and describe the old Fourche Maline burial mound tradition. Then I will try to show that the earliest mounds at Crenshaw were built in that tradition. Finally, 1 will try to show how that tradition was interrupted and significantly altered around A.D. 800, and I will argue that the Emergent Mississippians were behind this transition. 


\section{Was There a Fourche Maline Burial Mound Tradition?}

The earliest confirmed mounds in the Caddo area are the small, dome-shaped burial mounds and, apparently in at least two cases, buried structure mounds at the Cicero Young, Shane's Mound, and Red Hill sites in the Red River Valley in Arkansas (Schambach 1982), the Bellevue and McKinney sites in the Red River Valley in Northwest Louisiana (Fulton and Webb 1953), and the Jonas Short and Coral Snake (McClurkan et al. 1980) mounds in the Angelina and Sabine drainages in East Texas and extreme North Central Louisiana. These are probably mostly Marksville period mounds, to judge from various diagnostics, particularly the Marksville Stamped and Marksville Incised pottery found in two of them. But a few of them may be pre-Marksville period. This means they probably date to various parts of the time span between approximately 100 B.C. and A.D. 300. They are not, however, Marksville mounds that just happened to be built beyond the western edge of the Marksville homeland in the Lower Mississippi Valley. Some of them are probably too early, for one thing. Also, there are enough of them, and--as I will show shortly-they differ sufficiently from what seems to be the Marksville pattem of mound building to indicate that they represent an independent, regionally distinct, early Fourche Maline mound building tradition.

Seven mounds might not seem like much basis for this assertion, but we need not have hundreds or even dozens. The Marksville mound building tradition rests on the evidence of just 26 confirmed mounds from a territory almost twice as large as the territory that seems to have been occupied by Fourche Maline mound builders (Toth 1988: Figure 3 ), And only four or five of those have been reasonably well excavated and reported. Still, seven mounds would not seem to be enough unless we could reasonably assume, as sludents of the Marksville tradition assume, that these seven confirmed mounds are not the whole story. I think we can make that assumption. As I pointed out years ago (Schambach 1982:179-181), there are about 15 additional mounds in Southwest Arkansas that are probably of this type. More recently, Story (Story et. al. 1990:279, 290 and Figure 41) listed five other possible Fourche Maline mounds in East Texas and Northwest Louisiana. There are probably still more of these inconspicuous little mounds out there on the bluff edges along all the major rivers in the Caddo Area, waiting to be discovered. There were probably others down on the floodplains that got washed away, plowed away, or dug away, long ago. Also, it is worth remembering that while the number of burial mounds attributable to this period between 100 B.C. and A.D. 300 is small, it is commensurate with the number of good habitation sites, which is also small. It's not as if we had dozens of villages and just a few mounds. So I think we have the wherewithal to talk about a Fourche Maline mound building tradition that began during the early Marksville period, if not before, and that, by the end of the Markeville period, was well established throughout the territory that was to become the Caddo Area.

How do we know that, as I asserted above, these Fourche Maline area mounds are not basically just stray Markeville mounds that were built because the Marksville mound building tradition somehow diffused into Fourehe Maline territory along with the small amounts of Marksville pottery that appear at Fourche Maline sites in the Red River and Ouachita River drainages? Does the Marksville pattern of mound construction and usc differ from the pattern that seems to be exemplified in these Fourche Maline mounds?

Although students of Marksville culture are having difficulty working out exactly what the Marksville mound building pattem consisted of, hampered as they are by having passable data from only a few mounds (Toth 1988:29-42), it is clear that it does differ from the Fourche Maline pattern (which I am about to describe) in at least five very basic respects.

First, the essential element of the Marksville pattern seems to have been the placement of the mostly complete remains of large numbers of people, and modest quantities of offerings, particularly pots (Ford and Willey 1940:44-45), on earthen platforms that were then covered by dome-shaped mounds (Ford and Willey 1940:Figure 
8). Sometimes there are layers of human skeletons, as in Mound A at the Crooks site, where the remains of more than 1000 people were found in the various levels. Although the number of interments per mound varies considerably (only 35 to 65 were buried in Mound 4 at the Marksville site), it is generally large enough to suggest that in Markeville culture mound burial was not reserved for the elite. The incidence and distribution of offerings, and the types of offerings found in these mounds, suggest the same thing. The incidence was low. Only about 16 percent of the skeletons in Mound A at the Crooks site had anything with them, and most of the offerings were pots. No individuals were distinguished by the placement of large quantities of offerings.

Secondly, in Marksville culture the privilege of mound burial was not reserved just for people. In Mound A at the Crooks site, three dog skeletons were found at the feet of three human skeletons (Ford and Willey 1940:41). Since dog burials were found in the Troyville period Gold Mine site (Jeter et al. 1989:151) and the remains of 11 dogs werc found in the various Coles Creek period mounds at the nearby Greenhouse site (Ford 1951:107), the burial of dogs in mounds was evidently a deep seated custom in the Marksville-Troyville-Coles Creek burial mound tradition.

Third, it seems apparent both from the large numbers of human skeletons that are generally found in Marksville mounds and from their condition that the bodies they represent had been kept in charnel houses before burial (Ford and Willey 1940:40).

Fourth, although no systematic attempt was made to determine the sexes of all the 1156 skeletons in Mound A at Crooks, or of the 35 to 65 in Mound 4 at Marksville, the excavators thought both sexes were present (Ford and Willey 1940:40); the large numbers of skeletons found makes that seem likely.

Lastly, there are no cremated remains in Marksville mounds and there is no evidence of crematoria.

To anticipate the detailed descriptions presented further on, the mounds of the early Fourche Maline tradition are practically the opposite of Marksville mounds in all of these respects. They frequently cover crematoria and it may be true that the earliest mounds invariably do. There are no platforms piled with human skeletons. The numbers of people interred are invariably small and their remains are generally cremated or incomplete. The incidence of offerings per person is high. In fact, it is off the scale compared to Marksville, even though the number of offerings per mound is generally lower. The types of offerings, which run heavily to boatstones and projectile points, suggest that mound burial was mostly for males. Unfortunately, the skeletal remains are not much help here, since they tend to be sparse and are either fragmentary or cremated. At Bellevue, the one site where someone has hazarded a guess as to the gender of the person or persons represented by cremated bone, the guess was female (Webb 1984:258). But there were no offerings with this burial and, in fact, there were none elsewhere in the excavated part of the mound. Finally, no dog remains were found in any of these mounds.

Thus, while Marksville (and Troyville and Coles Creek) mounds seem to have been for the masses and a few dogs, early Fourche Maline mounds seem to have been for the human, perhaps mostly male, elite, and no dogs allowed. The charnel house was clearly an important part of the Marksville mortuary pattern. The funeral pyre was equally important in the early Fourche Maline tradition, though the exposure of bodies in some manner was evidently practiced as well.

The latter trait, exposure of bodies to the point where the ligaments decompose and the skeletons come apart, is one of the three similarities between these traditions. Bundle burials and isolated skulls appear in both Marksville mounds and Fourche Maline mounds, but not, of course in the same numbers. The second similarity is that in both traditions the mortuary offerings tend to be mostly standard issue Middle Woodland prestige goods and there is a fairly high incidence of Hopewellian imports, particularly artifacts of copper. This could be construed as evidence for a Marksville-Fourche Maline exchange system but I think it makes just as much sense to argue, as I will presently, that each culture had its own Hopewell connection. The third similarity is Marksville pottery. But the thing to note about 
the Marksville pottery from Fourche Maline mounds is that it is limited to two Marksville Stamped pots, one from the Red Hill mound and one from the Coral Snake mound, and to some Marksville Stamped sherds in the McKinney mound. This is interesting evidence of a Marksville connection, but it is hardy enough to make these mounds Marksville mounds.

\section{The Fourche Maline and Early Caddo Mound Building Traditions}

How do the seven known early Fourche Maline mounds (Cicero Young, Shanes, Red Hill, Bellevue, McKinney, Jonas Short, and Coral Snake) mounds relate to the early Caddo mound building tradition? Not very well, although there are a few similarities that may be significant indicators of generic continuities of various kinds between the two. The idea of using mounds for the burial of fairly small numbers of people--ostensibly, members of an elite rather than everyone in the society--seems to be basic to both. So does the idea of using exotic goods as grave offering. Cremation is another common element. It was not a major element in the Caddoan pattern, but it was a persistent and therefore probably not unimportant minor one. Certainly it would be easier to derive the Caddo burial mound tradition from this early Fourche Maline tradition than from the Marksville-Troyville-Coles Creek tradition, which started out differently in the Marksville period, with its emphasis on mass interments in mounds, and continued to diverge through the Coles Creek period, by which time (in strong contrast to the Caddoan tradition) Lower Valley people had ceased entirely to put offerings in their mounds (Schambach 1982).

But when it comes to specific traits, these earliest Fourche Maline mounds are plainly different, as a group, from Caddoan mounds, so much so that I find it hard to see how the one tradition could have been the forerunner of the other unless there was a substantial infusion of new ideas at some point. The contrast becomes especially pronounced if you seriate the earliest Fourche Maline mounds, as I am about to do, in order to try to see how they link up with what could reasonably be considered the late Fourche Maline and early Caddo mounds at the earliest Caddo ceremonial center we know of, the Crenshaw site located in the Red River Valley in Miller County, Arkansas. Then it becomes apparent (to me, anyway) that the latest early Fourche Maline mounds, which were probably built between A.D. 200 and A.D. 300, are surprisingly similar to the earliest mounds at Crenshaw, particularly to Mound D, which probably dates between A.D. 600 and 700 , but also to the early stages of Mound $C$, which may be slightly later. They are so similar, in fact, that it seems obvious that Mound D and early Mound C at Crenshaw were themselves Fourche Maline mounds rather than early Caddo mounds. But it is also apparent that those mounds are substantially and significantly different from what came next at Crenshaw. In other words, the Fourche Maline burial mound tradition seems to have ended at Crenshaw around A.D.800, when it was either transformed or replaced by a new and different burial mound tradition.

\section{The Fourche Maline Burial Mound Tradition}

The earliest of the seven excavated Fourche Maline mounds on record are the Cicero Young mound (Schambach 1982:146) located on the edge of the prominent bluff line that overlooks the Red River Valley on the east side of the river not far from Lewisville, Arkansas, and the Bellevue mound, ${ }^{3}$ which is on a 60 -foot terrace overlooking Bodcau Bayou on the east side of the Red River in Northwest Louisiana (Webb 1984:257 and Figure 1). Both were small dome-shaped mounds between 60 and 80 feet in diameter and 7 to 10 feet high, roughly the size range of all these early Fourche Maline mounds. Both covered centrally located fireplaces with associated burned human bone and, at Cicero Young, a Gary point and two shell beads. Partial post mold patterns beneath both mounds indicate the fireplaces were inside some kind of screen, at least, or possibly even a flimsy structure. Evidently these mounds mark the sites of bluff edge crematoria where 
dismembered bodies or bones were burned in small fireplaces in the Adena-Hopewell mode described by Brown (1979:213-215).

The final resting place of some of the products of the Cicero Young crematorium was probably the "cremation cemetery," consisting of numerous closely spaced small pits full of cremated human bones, that I found at the Johnny Ford site (Schambach 1982:145-146). Johnny Ford is a little early Fourche Maline village site located down in the Red River Valley, but only about 2 miles from Cicero Young. If I am right about this connection, bluff edge crematory mounds like those at Cicero Young and Bellevue may date as early as 100 to 200 B.C., the approximate age of the Fourche Maline component at Johnny Ford. Considering that the cremation cemetery there probably contained many more interments than the 12 we excavated, and that the cremation pit at Bellevue contained the burned bones of a child of two or three years and of an adult who--as mentioned earlier--was probably female (Webb 1984:258), it is possible that during early Fourche Maline times most if not all of the dead were processed in bluff edge crematoria like those at Cicero Young and Bellevue.

So these two mounds suggest that the Fourche Maline mound building tradition began as early as $200 \mathrm{~B}$.C. with the construction of low mounds over bluff edge crematoria and associated cremated human remains and artifacts. That is a far cry from the earliest mounds at Crenshaw, which must have been constructed beginning about 700 years later, and I would not dream of linking the two without some evidence of intermediate stages. But I think we have evidence of two such stages.

The earliest of these is represented by two mounds. One is "Shane's Mound" (Schambach 1982:449), located a mile or so from the Cicero Young Mound in the Red River Valley. The other is the Jonas Short Mound (2.4 meters high, 29 meters in diameter located about 150 miles to the southwest in the Angelina River Valley in East Texas (McClurkan et al. 1980). Despite the distance between them, these mounds were virtually identical. Unlike Cicero Young and Bellevue, both are alluvial valley mounds rather than bluff edge mounds, a circumstance that I consider a significant step in the direction of the Caddo burial mound tradition. Like Cicero Young and Bellevue, both covered central pits that contained cremated human bone. But the pits in these mounds also contained Hopewellian-looking Middle Woodland prestige goods: two copper bracelets at Jonas Short; and, at Shanes Mound, an owl effigy "boatstone" carved from bone (probably human), a well polished grooved boatstone (of stone), a disc-shaped pendant $10.8 \mathrm{~cm}$ in diameter cut from a human skull, and eight Gary points. Furthermore--and this is more important than the central pits as far as my seriation is concerned--there were also small deposits of prestige goods, at least some of them with parts of human skeletons, possibly just skulls, in the mounds themselves. Two of these deposits were found in the Shanes Mound and five in the Jonas Short Mound.

As Story (Story et. al. 1990:282) observed in the case of Jonas Short, these deposits were not in pits. Evidently they had been laid on various intermediate surfaces and then simply covered with soil as the mound was being built. This is the earliest evidence we have of this custom, a custom destined to become one of the major modes of mound burial by A.D. 600 to 700 at Crenshaw. Many of these caches contained boatstones. This is apparently another link with Crenshaw, because there was a boatstone in one of the deposits of prestige goods in Mound D there. There were also worked and unworked quartz crystals, Kent points, at least one Gary point, and small clusters of pebbles that may have been the remains of gourd or turtle shell rattles. Similar collections of pebbles were found in the mortuary deposits in Mound D at Crenshaw. Cache 2 at Jonas Short contained a reel-shaped copper gorget, 11 perforated elk teeth, four chipped bifaces of exotic stone, and a probable fragment of human skull.

Although, as I have said, there is little or nothing that could be considered diagnostically Marksvillian in these mounds and much that is clearly the antithesis of the Marksville tradition, the same may not be true of Hopewell. The emphasis on the burial of the remains of very small numbers of presumably important individuals rather than groups 
of people is certainly more Hopewellian than Marksvillian and could have been Hopewellinspired. The copper artifacts found at Jonas Short suggest not just Hopewellian inspiration but a Hopewellian connection of some kind. Considering the rarity of copper artifacts at Marksville sites (and thus their probable high value to the Marksvillians and the low probability that they would have willingly passed them on to their Fourche Maline neighbors to the west), it seems likely that the Fourche Maline groups obtained their own copper via their own contacts with Hopewellians to the north, or with intermediaries to the north. Another link with the north is that both mounds contained boatstones made of syenite that probably came from the big syenite outcrops in the vicinity of Little Rock, Arkansas. Boatstones are a Marksville trait too, of course, but not--as far as we know-syenite boatstones. The 10 from the Crooks site were made of sandstone, limonite, pumice, yellow ochre, leopardite, and chalk (Ford and Willey 1940:I06). Syenite, a distinctive and easily recognized stone, is not on Toth's list of exotic raw materials commonly found in Marksville contexts (Toth 1988:65-70) .

The earliest solid evidence of a Marksville connection, Marksville Stamped pottery, comes from the last three mounds in this group of seven that I am trying to seriate: the McKinney mound on Black Bayou on the west side of the Red River in Northwest Louisiana (Webb 1984:262-264), the Red Hill mound in Arkansas (Schambach 1982:147), about 5 miles down the Red River bluff line from Cicero Young, and the Coral Snake mound on the floodplain of the Sabine River in west central Louisiana (Story et. al. 1990: 287-289) . The Marksville Stamped pottery in all three, and three uncorrected radiocarbon dates from Coral Snake (A.D. $20 \pm 100$, A.D $180 \pm 80$ and A.D $300 \pm 90$; Story et. al. 1990:285 and Table 67), indicate that these mounds were built between A.D. 100 and A.D. 300 .

The little McKinney mound, which was only four feet high and 50 feet in diameter, probably wouldn't have been noticed or excavated by anyone had it not been on the farm of Ralph McKinney, a veteran amateur archeologist and a long time co-worker of Clarence Webb's, a circumstance that offers good reason to believe there are many more like it out there waiting to be discovered. In any case, McKinney did notice this one and he did excavate it. It proved to be a simple but enigmatic structure consisting entirely of "dark, charred sand" with a darker, charcoal-stained area near the center and about 2 feet down. This feature, probably detritus from a crematorium, yielded charred human teeth, small pieces of bone, and 45 beads, 42 of stone and three of rolled sheet copper. Elsewhere in the mound were 12 sherds, two of which were Marksville Stamped var. Markeville or Manny (Webb 1984:262-263). If they are really the Manny variety, this mound must have been built about A.D. 300 or later. But probably not too much later, because the other two mounds also contained rolled copper beads, which are starting to look like a nice horizon marker for this A.D. 100 to 300 period.

We know nothing about the innards of the Red Hill mound (1.2 meters high, 19.8 meters in diameter) except that an archeologically naive local woman who wanted just one Indian pot for herself, went there, dug one small hole, immediately found a perfect little Marksville Stamped pot (Schambach 1982:Figure 7-3) containing 13 rolled copper beads or bangles, and quit. I used to think this story (it is true--I talked to the woman when I photographed the pot and the beads) was just a remarkable example of beginner's luck. But after reading Story's (Story et. al. 1990:283) excellent synthesis of the confusing data from the Coral Snake mound, I suspect that she was not as lucky as she seemed. The Red Hill mound may have been crammed with deposits of bones and offerings the way the Coral Snake mound was and she might have found more if she had dug another hole.

According to Story (Story et. al. 1990:283), the Coral Snake mound, which was not appreciably larger than any of those discussed so far ( 24 meters in diameter, 2.5 meters high), contained 73 features: "10 fire basins, 35 cremations, 14 bundle burials, 14 deposits (or caches) of artifacts, some with human skeletal remains, and one postmold-like disturbance." The list of artifacts found in the caches (Story et. al. 1990:Table 66) includes a Marksville Stamped pot, a plain jar, rolled copper beads, a copper pendant, and 19 
perforated raccoon teeth. Several of the caches also contained human teeth possibly representing, according to Story (Story et al. 1990:286), "offerings of teeth or all that remains of a jaw or trophy skull." Artifacts from the cremations and other features included copper earspools, a boatstone, a quartz figurine, and dart points and bifaces of various types. Most of the caches and bundle burials were not in pits but had simply been laid on the surface and covered. That may have been true of most of the cremations as well.

Except for the two pots and the sheer quantity of features, Coral Snake is certainly similar enough to the other Fourche Maline mounds in this series to indicate that there was continuity, and that it was part of the same tradition. But, as Story has pointed out, there are also some significant differences. The main one is that this is the first mound in this series that was not primarily a buried crematorium with other features added. In fact, this mound may not have covered or otherwise included the remains of crematoria of any sort. Story suspects that the "fire basins" it reportedly contained were actually deposits of detritus from fires that burned elsewhere. But, even if it did cover a few cremation pits, it seems obvious that here (and probably at Red Hill), we have--for the first time in this sequence--a mound that contains the remains of a fairly large number of people that were processed in charnel facilities and crematoria located elsewhere, rather than the remains of a fairly small number that were processed in situ.

So by A.D. 300, it would seem, Fourche Maline mounds had become primarily repositories for human remains and offerings rather than primarily coverings for crematoria. And mound burial no longer seems to have been the privilege of just a few people. It certainly was not for everyone, as it may have been in Marksville culture, but it may have become the prerogative of one or more lineages rather than of certain individuals.

I do not know what might have caused this shift in mound usage. Since it could be construed as a shift in the direction of Marksvillian burial customs, and it seems to have coincided with the first appearance of Marksville pottery in Fourche Maline mounds, it is possible that Marksville influence was involved. But this was not a full scale intrusion of Marksville burial customs. Cremation is not a Marksville trait, nor was the practice of putting only incomplete skeletal remains--bundle burials, teeth, mandibles and skulls--in mounds.

Probably the Marksville influence was superficial as far as Fourche Maline mortuary customs were concerned, perhaps limited to the introduction of a little trade pottery and to the introduction of the idea of putting pottery in mounds. The more basic shift towards burying the remains of more people in mounds could, I suppose, reflect internal developments in Fourche Maline culture.

The thing to note, in either case, is that these changes in mound usage were also changes in the direction of what we find in the earliest mounds at Crenshaw some 300 years later. Although there are superficial differences, and although there is not one excavated mound on record for the 300 years that intervene, it is apparent to me that the Coral Snake mound at about A.D. 300 and Mound D and the early stages of Mound C at Crenshaw at about A.D. 600 to 700 were part of the same tradition.

If that seems farfetched as a proposal for the origins of the early mounds at Crenshaw, consider the alternatives. We can not derive the Crenshaw mounds from somewhere in the upper end of the Marksville-Troyville-Coles Creek burial mound tradition, because--as I have pointed out more than once--Coles Creek mounds are just as divergent from the earliest mounds at Crenshaw as Marksville mounds are from the early Fourche Maline mounds (Schambach 1991). In Coles Creek mounds the skeletons seem to have been literally thrown on mound platforms and covered up, sanitary landfill style (Ford 1951:106-107 and Figure 11). There are no grave goods. And it appears that more dogs were buried in Coles Creek mounds than in Marksville mounds.

The only other possible alternatives 1 know of (the Arkansas Valley of eastern Oklahoma is out because there are no known burial mounds there this early) are Plum Bayou culture, centering around the Toltec site in Central Arkansas (Rolingeon 1982), and early Weeden Island culture on the Florida Gulf Coast (Milanich and Fairbanks 
1980:89-143). Plum Bayou culture is out because even though there are some apparent ceramic ties between it and the earliest occupations at Crenshaw, all we know about Plum Bayou burial mounds is that two mounds at loltec yielded human remains when they were tested superficially.

Weeden Island culture is also out as a source of this complex in toto, though not necessarily as a source for some new ideas. Despite certain similarities in ceramics (which it also seems to share with Plum Bayou culture), and despite some generic Southeastern similarities, such as placements of isolated skulls and bundle burials, Weeden Island mounds are significantly different from the Crenshaw mounds. The big Weeden Island-style caches of killed pots are missing at Crenshaw; the numbers of people represented are generally larger in Weeden Island mounds; and the stone-lined central tombs common in Weeden lsland mounds are, of course, missing as well. Even if the similarities were stronger, it would still be difticult to derive the early Crenshaw mounds from Weeden Island because we would also have to explain how the Weeden Island mound building complex might have moved from southern Alabama and Mississippi to the Red River Valley around A.D 600 when the people between in the Lower Mississippi Valley had a different mound building tradition.

So I think the historical link that I have just proposed between the Coral Snake mound at A.D. 300 and Mounds D and $C$ at Crenshaw at A.D. 600 to 700 is the most probable one that can be found. Therefore, let me try to show exactly how these mounds appear to connect with the old Fourche Maline burial mound tradition.

\section{Linking the Early Mounds at Crenshaw with the Old Fourche Maline Burial Mound Tradition}

The earliest excavated mound at Crenshaw, and probably the earliest one on the site, was Mound D. According to Judge Lemley's unpublished notes and drawings, it was about seven and a half feet high and 60 feet in diameter originally, and it was "composed of layers of sand separated by thin layers of clay ranging from 2 " to 4 " in thickness." Each layer of sand contained human remains and offerings that had been placed on a mound surface and covered up in what I would call the old early fourche Maline style that dates back to the Shanes Mound and the Jonas Short mounds at about A.D. 100.

Everyone who dug in this mound (which includes C.B. Moore, Glen Martin, and Judge Harry J. Lemley) thought the invariably incomplete human remains they found-usually just skulls or teeth-were all that was left of corpses or skeletons that had been complete when they were interred. Almost certainly, they were wrong. Considering: (a) the old Fourche Maline burial pattern, (b) what Raymond Wood found in contemporaneous levels in Mound C (see below), and (c) the fact that skulls are no more resistant to decay than other major bones in the human skeleton, particularly the long bones, I think the real burial pattern was otherwise. It must have consisted of the placement of just the human skulls, mandibles, and teeth the excavators actually found, never complete bodies or skeletons or postcranial parts thereof, on successive mound platforms. Sometimes artifacts (whole pots, arrow points, one boatstone, and some small chisel-like woodworking tools) were placed with or near them. Except for one cluster of five skulls, the placements of bones and artifacts seem to have been confined to the south half of the mound.

Prominent among these placements were pots of very early varieties of Coles Creek Incised (i.e., varieties Hunt, Stoner, and Campbelleville), of the types French Fork Incised ${ }^{4}$ and of Williams Plain. Many of the Coles Creek Incised and French Fork Incised pots are obviously exotic to the Crenshaw ceramic assemblage in style, paste, and workmanship. The Coles Creek Incised varieties represented have known or estimated time ranges in their presumed Lower Mississippi Valley homeland that collectively span the Deasonville, Bayland, and Aden phases of the Baytown and early Coles Creek periods (Williams and Brain 1983:Higure 12.1). However, most of them either fall within the Bayland phase or look as if they might have ranged into it, although they are more at home 
in earlier or later phases. The time range for this period is approximately A.D. 550 to A.D. 700 (Phillips 1970:76) and, all things considered, ${ }^{5}$ Mound D was probably in use between A.D. 600 and A.D. 700.

So much for the traditional argument that the earliest mounds at Crenshaw are "Coles Creek" mounds. The earliest mound building at Crenshaw predates the Coles Creek period and the appearance of Coles Creek Culture in the Lower Mississippi Valley by between 100 and 200 years. That is a long time.

In any case, I think the links between what was found in this mound and the old Fourche Maline burial mound tradition are clear. During the 300 years that separate Mound $\mathrm{D}$ at Crenshaw from the Coral Snake mound, cremation ceased to be an important part of the Fourche Maline burial program, although it probably hung on in a minor way. But the practice of removing parts of bodies, particularly skulls, mandibles, and teeth, from charnel houses, scaffolds, or graves and burying them on mound surfaces continued. There were skulls and teeth in the Coral Snake Mound and skulls and teeth in Mound D. ${ }^{6}$ The practice of placing male-associated artifacts in mounds continued too, but arrows and--I am sure-bows, supplanted atlatls and darts. The single syenite boatstone Lemley found in Mound D is evidence of continuity. Copper was probably still being used. The custom of using pots, particularly imported Lower Mississippi Valley pots, as mortuary offerings that looks as if it was just getting underway around the time the Coral Snake and Red Hill mounds were built, was in full swing at Crenshaw 300 years later. But by then the pots were, of course, Troyville and Baytown pots rather than Marksville pots. Thus, as I have said, Mound D was not a "Coles Creek" mound. Nor was it, in the sense that it was clearly in the early Caddo tradition, an early Caddo or proto-Caddoan mound. It was a late Fourche Maline mound, one of the last representatives of a seven to eight century-old Fourche Maline mound building tradition in and around the Red River Valley in Southwest Arkansas, Northwest Louisiana, and Northeast Texas.

Although Mound $\mathrm{C}$ at Crenshaw is best known for the rich, deeply intrusive, early Caddo "shaft" graves it contained(Durham and Davis 1975), the first trained professional archeologist to dig at Crenshaw, Raymond Wood, found clear archeological evidence that its early stages were constructed in approximately the same manner as Mound D (Wood 1963a: 1-14, 1963b:38-39). These consisted of no less than two superimposed platforms upon which parts of human skeletons and clusters of artifacts had bcen placed and buried. Construction of the earliest platform probably began between A.D. 700 and 800, to judge from age estimates (Phillips 1970:71; Williams and Brain 1983:Figure 9.4) that seem to apply to the large fragment of a Coles Creek Incised var. Camphelleville bowl Wood found in the sub-mound midden. This platform, which was at least 2.25 meters high finally, was built mostly of "laminated brown and light buff sand but there was clear evidence within [it]... of successive accumulations of soil, perhaps representing substages in its construction" (Wood 1963b:38).

Wood, who was trying against long odds to discern the construction history of Mound $\mathrm{C}$ from one small central block that survived the destruction of the rest of the mound by untrained looters led by Glen Kizzia (see Wood 1963a), found no evidence pertaining to the function of this platform. But, knowing from his own work that the overlying platform (Stage 2) contained skeletal remains and offerings similar to those I have just described from Mound D, he suggested that the "successive accumulations of soil" might be deposits that had been "piled over surface burials that were not found by the excavations" of Kizzia and his crew (Wood 1963b:38).

Platform (or Stage) 2, the completion of which brought the mound to a height of 5.35 meters, consisted of two major strata, C and D. These were composed of "fine, homogeneous sandy layers" and these "layers" contained all of the Fourche Maline burials that Wood found. "Contained" is the right word for, as just noted, these burials (with one exception, Wood's Burial 42, discussed below) were not intrusive from elsewhere within or above the Stage 2 platform. They had been placed on one or another of the Stage 2 
subsurfaces represented by the "sandy layers" within Strata C and D and covered with mound fill.

The mortuary placements Wood (1963b:39-42) found in Stagc 2 included ${ }^{7}$ : the isolated skull of a child (Burial 15) with offerings consisting of four Homan points and three copper beads; the skull of an adult (Burial 1) with offerings of a large, side-notched, bifacially chipped knife somewhat like the "Gahagan knives" found in early Caddo burials, 13 Homan points, and "at least two copper ornaments," all placed atop a few postcranial bones; a small scatter of pieces of human long bones (Burial 6); and a single more or less complete skeleton without offerings (Burial 5). Apparently Kizzia and his crew found similar placements at various locations in Mound $C$ but did not recognize them as such. Kizzia's "Burial B," with five Coles Creek Incised and "French Fork Incised" pots, eight Homan points, and a cluster of human teeth was clearly such a deposit (Durham and Davis 1975:Figure 5). The specimens from the left, or north, two-thirds of Kizzia's "Burial C" (Durham and Davis 1975:Figure 7) evidently represent another one. In this case, as Durham and Davis (1975:17-18) suggest, a Caddoan grave must have intruded an earlier cluster of mound surface interments of the same age, on typological grounds, ${ }^{8}$ as those in "Burial" B. Kizzia's "Burial G," consisting of a piece of a French Fork Incised bowl, a Coles Creek Incised var. Campbellsville bowl, and deposits of 44 and 32 Agee points (Durham and Davis 1975:31 and Figures 2 and 16) located not far east of the Burial C cluster was probably yet another.

To summarize: as far as Mounds C and D are concerned, the pattern of mound burial at Crenshaw from about A.D 600 to around A.D. 800 consisted of placing modest numbers of human skulls, mandibles and, perhaps, teeth, along with offerings of artifacts, on successive surfaces of small to medium-sized platform mounds and covering them with layers of earth. As I have tried to show, this is fundamentally an old Fourche Maline pattern, with perhaps some Hopewellian overtones, that began to develop around 100 B.C., if not earlier, in and around the Red River Valley. Unlike the Marksville-Troyville-Coles Creek tradition with its pattern of mass burials in mounds, this seems to have been a tradition in which mound burial was reserved for small numbers of people of a high or otherwise distinctive status. Other people were buried in their villages in shallow graves (with few or no offerings) that were probably emplaced near the houses they occupied in life.

There is one major glitch in this pattern, namely the mass burial beneath Mound $\mathrm{F}$ at Crenshaw (Schambach 1982:156-158). This burial appears (it has not been excavated completely) to represent a ceremony or series of events in which the remains of more than 60 people, some complete but many of them disarticulated and incomplete, were taken from charnel houses or scaffolds, or disinterred from graves, and placed with modest offerings of pottery, arrow points, and food, in a shallow, circular pit about 50 feet in diameter that was then covered with a low mound. A large fire was built atop part of the grave after the first $10 \mathrm{~cm}$ or so of the capping mound were laid down. Subsequently, but not necessarily immediately after or even as part of the burial ceremony, a thin layer of rich culinary refuse, possibly the remains of a ceremonial feast, was laid down and the mound was quickly raised to something over 21 feet in height.

The grave goods consisted of about 50 arrow points, many of them Agee points, and seven pots: one Williams Plain jar, one globular bowl of Coles Creek Incised var. Chase, one half gourd-shaped vessel of Coles Creek Incised var. Keo, two plain bonetempered bowls, and one plain platter. This ceramic assemblage, particularly the Coles Creek Incised var. Chase bowl, a variety considered "late Baytown or early Coles Creek" by Phillips (1970:72) and Bayland phase of Baytown culture by Williams and Brain (1983:148 and Figures 9.4 and 12.1), suggests that the Mound $F$ burial was emplaced around A.D. 700. Virtually identical Coles Creek Incised var. Chase bowls were used as offerings in some of the Mound D and Mound C burials just described. Therefore, barring the ever-present possibilities that some of these were old curated specimens, or exhumed 
and reburied specimens, the Mound $\mathrm{F}$ grave must have been emplaced some time during the period (A.D. 600 to A.D.800) those mounds were in use.

The pattern that seems to be represented by this burial (i.e., the placement of large numbers of both complete and incomplete corpses or skeletons and a few offerings in a pit subsequently covered by a mound) is a radical departure from the old Fourche Maline pattern. I have no idea what might have inspired it. It resembles the possibly contemporaneous or possibly earlier burials in Mound $\mathrm{C}$ at the Greenhouse site (Ford 1951:42-45) in that complete and partial skeletons of a comparable number of corpses $(n=87)$ that had been exposed long enough to be reduced to, or slightly beyond, the ligamentous stage of decomposition, were found in a mound. But there the similarity ends. Although the skeletons and parts of skeletons in the pit under Mound F were not as meticulously arranged as skeletons almost invariably are in later Fourche Maline and early Caddo graves, neither were they "dumped on the surface more or less carelessly, raked into any shallow surface depressions and then covered" like those under Mound $C$ at Greenhouse (Ford 1951:43-44) . Furthermore, apart from 13 supernumerary skulls, most of the skeletons in Mound C at Greenhouse were mostly complete (Ford 1951:44), about what one would expect in a deposit resuiting from the burial of the contents of a nearby charnel structure. But about one-third of the individuals in the Mound $F$ pit were represented by what appear to have been token placements of bones, often only the skull and a few long bones. These remains were probably brought to Crenshaw from outlying sites where they had been exposed or interred for quite some time. Evidently this was not a Coles Creek idea. There is also the fact that in contrast to the "unrelieved lack of grave goods" that is characteristic of the Coles Creek mortuary pattem (Belmont 1967:32; Jeter et al. 1989:170), the grave under Mound F contained a modest number of offerings. Lastly, the Mound $F$ skeletons were interred in a pit that was subsequently covered by a low mound, something quite different from the Coles Creek practice of piling skeletons on platforms in existing mounds and covering them up. So this was not a Coles Creek burial, nor does it seem likely that it was even Coles Creek inspired in some way.

It is also hard to see evidence of any kind of relationship between this burial and the late Fourche Maline burials in the apparently contemporaneous Mounds D and C, or between it and the early Caddo mound burials that were emplaced beginning no more than one and two centuries later at Crenshaw and other sites. There are no parallels in Mounds $\mathrm{C}$ and D (where complete skeletons were generally absent) or in early Caddo mounds (where the skeletons are generally complete, fully articulated, and carefully laid out) for the relatively disorderly heap of whole skeletons and parts of skeletons found beneath Mound F. The size of the grave is also unusual. The late Fourche Maline burials in Mounds C and D tend to represent single individuals or, at most, two or three people. Similarly, while group burials seem to have been the norm in early Caddo mounds, the groups tend to be small, under 20 individuals usually, which is a far cry from the 60-some people represented in Mound F. Furthermore, this is the only example, so far, of a late Fourche Maline or Early Caddo mound built to cover just one enornoüs grave. These mounds usually cover and/or contain multiple smaller burials. The refuse layer covering the low mound that capped the burial pit also seems to be unprecedented in the Caddo Area, although it is possible that early excavators overlooked evidence for such activity in other early mounds--sucil as Mounds B and D--at Crenshaw. So Mound F is an enigma, a glitch in my evolutionary sequence.

\section{Emergent Mississippian Influence at Crenshaw?}

In any case, the Fourche Maline pattern of placing skulls, mandibles and, perhaps, teeth, along with offerings of artifacts on the surfaces of small to medium-sized platiorm mounds and covering them with layers of earth was itself either terminated or extensiveiy altered soon after the emplacement, probably no later than A.D. 800, of the burials Wood, and Kizzia and his helpers, found in Mound C. What came next was, in some important 
respects, radically different, namely the evidently rather short-lived practice of placing a large number of fully-fleshed corpses in a long row on a mound surface and burying them. The evidence for this is Kizzia's burials A, H, and S (Durham and Davis 1975:12, 33-36, $75-78$ and Figures 4,17 , and 42). These consisted of numerous (27 in A, 43 in $\mathrm{H}$, and 10 in S) presumably complete skeletons of adults, ${ }^{9}$ mostly placed supine and side by side in long rows ( 37 feet for $A, 47$ feet for $\mathrm{H}$, and 15 feet for $\mathrm{S}$ ) with very small numbers of grave goods. According to Durham and Davis (1975), Kizzia observed that these rows of skeletons were not lying in visible grave pits, which led him to decide that they were the remains of corpses that had been laid in a rows on the mound and covered with fill. That is plausible, considering the evidence I have just reviewed from this mound and from Mound D for the earlier Fourche Maline practice of interring disarticulated human remains and offerings by placing them on mound surfaces and covering them.

These graves foreshadow the distinctive early Caddo burials that were emplaced, probably beginning around A.D. 900 if not earlier, at Crenshaw and other important early ceremonial centers such as Gahagan, Mounds Plantation, Bowman, and Davis. The only significant differences are that the latter generally contain fewer skeletons and more offerings and that they were emplaced in deep pits that intrude the mounds rather than on mound surfaces.

During his salvage work in Mound C, Wood found one grave that must have been emplaced within a few years of the time the Kizzia burials were, yet it was in a shallow pit. This was his Burial $42,{ }^{10}$ a multiple interment that, after an unknown amount of the east end of it had been destroyed by Kizzia, stili contained the complete or partial skeletal remains, of "at least 8 individuals," those in the former category lying extended and supine. These had been placed, Wood was able to discern, although the "outline was very indistinct," in a $55 \mathrm{~cm}$ deep pit that originated from a higher surface within Stage 2 (Wood $1963 \mathrm{~b}: 40-41$ ). The artifacts from this grave, particularly a bowl with a combination of Coles Creek incised and French Fork Incised decoration (Wood 1963a:Figure 4b), indicate that it was at least as early as Kizzia's four mound surface burials.

This discovery raises the possibility that the burials Kizzia found were in similar pits but he--utterly untrained and inexperienced, as he was, and probably not very interested in stratigraphy anyway--did not recognize them. So we cannot be certain the burials Kizzia found really were mound surface burials. Assuming that they were, the general idea of placing human remains and mortuary offerings on a mound and covering could well be a continuation of the, as I have been arguing, very old Fourche Mialine tradition or custom of doing the same thing with skulls and mandibles. Thus, these graves would represent an (evidently short) intermediate stage in the transition, if such there was, between the old Fourche Maline style of mound burial on mound surfaces and the early Caddo style of mound burial in intrusive pits that is seemingly presaged by Wood's Burial 42.

But there is no precedent locally for burying large numbers of corpses, carefuliy arranged, in full flesh, in rows in communal graves, whether on mound surfaces or in shaliow intrusive pits in mounds. Where did this new pattern, which apparently foreshadows the early Caddoan pattem of the burial of (usually) groups of people carefully laid out in full flesh in deep intrusive tombs, come from?

Perhaps the enigmatic mass grave beneath Mound $\mathrm{F}$ represents a transitional stage between the old Fourche Maline pattern and this one. If so, I am afraid I will have to see more evidence from other mounds before I can understand how such a transition could have taken place.

Another possibility, one I have begun to consider seriously during the three years since I presented the original version of this paper to the East Texas Archeological Conference, is that the stimulus behind this new patiern of mound burial came from the Mississippian culture area to the northeast of the Caddo Area, perhaps from Cahokia itself. As far as I know, that is the only other place in the Southeast where similarly laid out fullflesh, group burials were being placed in mounds at roughly the same time as Kizzia's 
Mound C graves and Wood's burial 42 were emplaced. These burials are strikingly similar to some of the interments found in Mound 72 at Cahokia (Compare Durham and Davis 1975:Figure 2 with Fowler 1991:Figure 1.3).

Unfortunately the Mound 72 radiocarbon dates (Fowler 1991:Table 1.1) are all at least a century later than my estimated date of A.D. 800 for the graves in Mound C. But, considering the rudimentary radiometric chronology we have for Crenshaw, I think it would be premature to discount the possibility of a generic relationship. Some or all of my estimated dates for Mounds C, D, and F could be about a century too early. In fact, our only radiocarbon date from a mound at Crenshaw, an uncorrected date of A.D. $900 \pm 70$ (Schambach 1982:138), on the midden layer overlying the mass grave under Mound $F$, would seem to indicate that such is the case. I have always considered that date at least 100 years too late for the Mound $F$ grave because it does not jibe with its ceramic age, which is based on the presumably reasonably accurate Lower Mississippi Valley chronology. But it could be better than I think. Certainly that date would bring Kizzia's Mound C graves, which look a little later than the Mound $F$ grave, into better temporal alignment with the graves in Mound 72. Also, of course, the burial pattern reflected in Mound 72 probably had a lengthy history of development in the "Emergent Mississippian Tradition" of A.D. 750-900 in the American Bottom (Kelly 1991:68-73). If so, the (hypothetical) Emergent Mississippian stimulus for the mass graves in Mound $\mathrm{C}$ could have come out of an earlier period in that tradition.

But what would account for this putative Emergent Mississippian, if not Cahokian, stimulus? What possible connection might there have been between the Crenshaw site and far-off Cahokia around A.D. 800 to 900 that could have caused the late Fourche Maline peoples of the Red River Valley to alter their centuries-old burial mound usage so drastically?

The hypothesis I am developing (Schambach 1995:19, n.28, n.29) is that the Mound $\mathrm{C}$ graves, which also happen to contain what I believe to be the earliest essentially Mississippian trade goods (copper objects, polished petaloid celts of igneous rock, and "Copena" or "Gahagan" bifaces) to appear at Crenshaw or elsewhere in the Caddo Area, mark the earliest participation of the late Fourche Maline-early Caddo people of the Red River Valley in the Mississippian interaction sphere or "worid system" (Wallerstein 1974; Peregrine 1992; Sanderson 1995). The basis for this participation--the main reason for the interest of the Emergent Mississippians in the people of the Red River Valley--was, I am hypothesizing, bois d'arc (Osage orange), one of the two best bow woods in the world and by far the best one available in North America east of the Rocky Mountains (Schambach 1995:11-13).

As I have argued elsewhere (Schambach 1995:13), and as Lafferty (1994:201) has suggested independently, bois d'arc bows may have been a major, but hitherto almost completely overlooked, commodity in the prestige goods economy of the Mississippians. Furthermore, prior to the early $1800 \mathrm{~s}$ when Europeans began transplanting it across the continent, the range of bois d'arc (at that time a relic species that had barely survived the end of the Pleistocene and the extinction of the Pleistocene animal vectors, probably horses, that originally propagated it) seems to have been limited.to an extraordinarily small area in the Red River Valley in Northeast Texas (Schambach 1995:18-19, n.27). This, in my view, probably gave the Red River Valley Caddo a monopoly on the most powerful, accurate, and durable bows to be had in eastern North America. Such a monopoly might well have drawn them into the Mississippian world-system.

Thus by no later than A.D. 1100 (or so I have argued on what I consider sound archeological and bioanthropological evidence), long-distance traders from Spiro had established the Sanders site in Northeast Texas as an entrepot for the collection of bois d'arc bows. By then the Sanders site was, I think, the vital southwestern node of a well-developed Mississippian world-system that supplied the Red River Caddo with Mississippian prestige goods in exchange for bois d'arc bows. These included the conch shell cups, shell pendants, shell beads, pearl beads, "Long-Nosed God" maskettes, copper 
beads, ear spools of various styles, coomorphic tobacco pipes, chumky stones, polished stone celts, and exotic projectile points that made their way into the graves of the Caddo eite at all the major Early Caddo ceremonial centers, notably Crenshaw, Gahagan, Bowman, Mounds Plantation, and the Davis site.

According to world-system theory (Champion 1989; Dincauze and Hasenstab 1989), the presence of these clearly exotic, clearly Mississippian, prestige goods in the graves of the Caduo elite at all of the early Caddo ceremonial centers signifies much more than just "trade" with Mississippians to the north. One of the major tenets of world-system theory is that as a satellite suciely is drawn into a world-system it tenu's to develop an elite class similar to the elite of the society controlling the world system.

Thus, it would be no coincidence that the high status mound burials of the early Caddo, aimost all of them replete with Mississippian prestige goods, are strikingly (and heretofore inexplicably) similar to high status burials that were emplaced at about the same time at Cahokia. Theoretically speaking, the Mississippian demand for bois d'arc bows woulu have siimulated the uevelopment of a Mississippian style elite anong the Reú River Caddo and these graves would be the end resuit of that stimulus. Hence the graves Kizzia and Woud found in Mund $\mathrm{C}$ at Crenshaw, the apparent precursurs of the "siraft tomb" buriais that would prevail for the Caddo elite from then on, would appear to mark the very begiming of that process around A.D. 800 . Or so it nuw seems io me.

\section{End Notes}

1. As I noted in my conference presentation, the origin of the Caddoan temple mound tradition is another story. Although mound building in the Cadiu Aned beyan in the Fourche Maline era, it began as a burial mound tradition, basically, and it remained a burial mound tradition until weil into the Caddo era. The earliest dates we have on Caddo temple mounds in Arkansas are some from the Hays mound on the Little Missouri River that fall around A.D. 1250 (Schambach and Early 1982:SW107-108). I suspect that we will not find temple mounds dating much earlier than that. Certainly most of the classic early Caddo sites (Crenshaw, Gahagan, Mounds Plantation, and Bowman) seem to have had only burial mounds. I have my doubts about the age of the structures on Mound A at the Davis site (Newell and Krieger 1949:68-70).

2. As I pointed out in the original version of this paper, the mounds of the su-called "Northern Caddo Area" in the Arkansas River Valley are exciuded from this discussion. This is by no means a doctrinaire exciusion. I have gone to great lengths (Schambach 1993 ) to point out how and why the culture history of the Arkansas River Valiey is distinct from that of the Caddo Area, and that is certainly true of the Arkansas River Valley mound building tradition. The Harlan phase burial mounds (Beli 1972, 1984:228-232) crammed, like loaves of raisin bread, with hunureds of indiviually placed, full-flexed skeletons have no counterparts in the Caddo Area. Nor do the Spiro phase burial mounds (Brown 1984:251-252) with their litters piled with prestige goods and their adjacent piles of skeletons. Nor do the flat-topped "structure mounds" of that area, which were always used only to cover the sites of burmed or dismantled structures, never as platforms for them. Excluding these clearly foreign Arkansas River Valley data from consideration is the necessary first step in working out the history of mound building in the Caddo Area.

3. My thanks to Jeff Girard of Northwestern State University for taking me to see the still substantial remains of this mound three years ago when I was writing the original version of this paper.

4. Although Lemley seems not to have realized it, there is an interesting and possibiy temporally significant difference between the pottery obtained by Martin and his associates 
from the six deposits they excavated in the "upper levels" of Mound D (all were between 14 and 30 inches deep) and that obtained by the Lemley expedition from the lower levels (everything below 30 inches). All of the French Fork Incised pottery is from the upper levels. In the six primary placements he excavated in the lower levels, Lemley (1936:30-36) found seven Williams Plain jars, which he rightfully described as "crude," and three Coles Creek Incised bowls (V1286, variety Stoner; V1287, variety Hunt; and V1287, variety Campbelleville).

5. The "things considered" are as follows: Lemley (1936:35) found a shallow bowl of Coles Creek Incised, variety Keo (V1293) in the sub-mound midden. This variety (Stewart-Abernathy 1982:44), said to be ubiquitous at Toltec, occurs there in contexts radiocarbon dated as early as A.D. $739 \pm 75$ and as late as A.D. $820 \pm 95$ (Rolingson 1990). Thus, it may well predate the earliest occupation at Toltec, which Rolingson (1990:40 and Figure 9) puts at A.D. 700.

The plain pottery jars (nine from all levels basically, and only plain pottery was found in the lower levels of the mound) fall into three shapes that I believe were early in the Williams Plain-LeFlore Plain tradition: a flat-bottomed beaker with straight, slightly flared sides and a thick, disc-shaped base (V1295 and V1474), a tall jar with a bowl-like incurved rim (V1292, V1445, and V1291), and a jar with a weak shoulder, a slightly constricted neck, and a slightly flared rim (V1285, V1288, V1294, and V1458). Absent, as if this mound were too early for them, are jars of the form that the latter four vessels scem to portend: jars with pronounced shoulders, strongly constricted necks, and strongly flared rims (see Lemley 1936:Plate 8, no. 4). This form appeared sometime during Fourche Maline period 6 (estimated time range of A.D. 500-800; see Schambach 1982:160-161 and Table 7-1) in the Dutchman's Garden phase. It is so abundantly represented in collections and photographs of pottery from the Fourche Maline middens and midden burials at Crenshaw that I doubt its absence from Mound D is due to chance. It is probably not due, either, to exclusion from mound burial on functional grounds (a rule against putting cooking pots in burial mounds, perhaps) because one jar of this shape was found in a (probably later) Fourche Maline burial pit under Mound B (Lemley 1936:49 and Plate 8, no. 4).

Two of the four earliest looking decorated pots in the mound are bowls (V1460 and V1465) with single rim lines that appear to be the local equivalent of Coles Creek Incised variety Phillips (Williams and Brain 1983:155-156; but see also Milanich and Fairbanks 1980:Figure 22 for Weeden Island Plain). The other two (V1287 and V1453) are bowls with two and three sloppily incised lines that fit descriptions of Coles Creek Incised variety Hunt (Phillips 1970:74-75; Williams and Brain 1983:151). Williams and Brain (1983:156) consider Phillips a Deasonville variety, while noting that "it also seems to continue into the Bayland phase." Phillips (1970:7475) called Hunt "the best available marker for the Deasonville phase of the Bayland period"--which in his estimation dates "300-550 A.D."-while Williams and Brain (1983:151 and Figure 9.4) opine that it "may be one of the earliest expressions of the type" and, likewise, assign it to their Deasonville phase "Reed 2" ceramic "set."

The succeeding Bayland phase of the Baytown period is represented by three vessels (V1286, V1459, and V1440), each with a lip line and a single rim line, that fit the description of Coles Creek Incised variety Stoner, by a half gourd-shpaed Coles Creek Incised variety Wade bowl (V1290), by one bowl (V1441) that is unquestionably Coles Creek Incised variety Chase and another (V1461) with a good Chase rim and a French Fork Incised body (both are certainly imports), and by six French Fork Incised vessels. Two of these (V1447 and V1449) are certainly imports, two (V1443 and V1464) are probably imports, and two (V1450 and V1451) are probably local copies of the type. Phillips (1970:76), with Williams and Brain (1983:Figure 5.65) concurring, calls Stoner a "marker of the Bayland phase in the Lower Yazoo sequence." He considers Wade a Bayland and Aden phase variety that may run earlier (Phillips 1970:76). Williams and 
Brain (1983:156) consider it Bayland. Chase Phillips (1970:72) considers "Late Baytown or early Coles Creek." Williams and Brain (1983:147-148 and Figure 9.4) refine that to the Bayland phase while noting, apropos--as it happens--of V1461, that "the Chase mode of rim decoration is sometimes found combined with other decorative types such as French Fork Incised" (see also Ford 1951:Figure 21c, e). The French Fork variety of French Fork Incised, which these and most other specimens from Crenshaw fit, has yet to be precisely dated, according to Phillips (1970:84). He noted that at Greenhouse it "falls on the line between the Baytown (Ford's Troyville) and Coles Creek periods" and that in the Yazoo "the few scattered occurrences... are suggestive of an Early Coles Creek date." The Coles Creek Incised variety Chase/French Fork Incised Rosetta bowl just mentioned leaves little doubt that the type was current during the Bayland phase.

Finally, there are four vessels (V1289, V1446, V1452, and V1466) that fit the description of Coles Creek Incised variety Campbellsville reasonably well, although each deviates slightly (none in the same way). This is generally considered an early Coles Creek (Phillips 1970:71), or Aden phase (Williams and Brain 1983:Figure 9.4), variety.

There are at least three possible explanations for the probably overly long time span represented by the decorated pots considering that they were, it will be recalled, all clustered in the upper levels of the mound. One is that the resemblances of vessels V1460 and V1465 to Phillips and vessels V1287 and V1453 to Wade are accidental, and that there are no Deasonville period decorated pots from Mound D. For that matter, this argument might be extended to the other simpler varieties of Coles Creek Incised that seem to be represented: the three Stoner vessels and the four Campbellsville vessels. But considering that the range of variation in the Coles Creek Incised pottery from this mound is limited to vessels with decorations which conform to normal Lower Mississippi Valley varieties (there are no pots decorated with Coles Creek-like configurations of horizontally incised lines that do not fit established varieties), the odds that even a seemingly simple variety like Phillips was mimicked accidentally are not high. The idea of placing a single horizontal line just below the lip of a bowl is, after all, not one that manifested itself here, there, and everywhere in the Southeastern pottery tradition. It was confined to a narrow time range and a limited geographical area within the Lower Mississippi Valley and along the eastern Gulf Coastal Plain, with extensions into the Trans-Mississippi South.

Second, there is the possibility--a good one, in fact, but impossible to test at this late date--that some of the decorated pots from Mound D were buried or otherwise kept elsewhere for some years before being placed in the mound. If so, the variety Campbellsville puts the time of interment at ca. A.D. 700 or later.

Third, the (albeit poorly) known time ranges of all the varieties represented overlap to the extent that it is possible they all coexisted briefly at Crenshaw around A.D. 700. This is the simplest explanation for the Mound D assemblage and probably the best one. Hence, I estimate that the construction and use of Mound D began around A.D. 600 and ended about A.D. 700.

6. The similar custom of burying large numbers of human skulls and mandibles in pits in a precinct adjacent to an off-mound temple that was manifested around A.D 1000 at Crenshaw (Schambach 1996:39-40) probably sprang from this ancient Fourche Maline tradition.

7. Wood also found two isolated skulls out on the peripheries of the mound (Burial 13 in the "northeast comer" and Burial 14 "on the east side" of the mound) in strata that contained "Coles Creek" pottery. Because of the damage done by Kizzia, these could not be correlated with the stratigraphy in the center.

8. The shared types are Coles Creek Incised var. Keo (Durham and Davis 1975:Figure 9, specimens C5, C6, C7, and C8) and var. Campbelleville (Durham and Davis 1975:Figure 9, specimens $\mathrm{C} 9$ and $\mathrm{C} 14)$. 
9. Unfortunately, the documentation for these extraordinary burials consists only of sketches made by Kizzia supplemented by Durham and Davis' descriptions, which are based on interviews with Kizzia and others who worked with him. The skeletons were not saved, so nothing will ever be known about the bioanthropological and demographic characteristics of this population of 80 Fourche Maline people. Since we lack the detailed observations on their condition in situ that Kizzia would not have been competent to make had he been disposed to do so, we cannot even be certain that the skeletons were complete or that they are the remains of full flesh burials as the sketches suggest.

The reason 1 am willing to accept Kizzia's sketches and recollections as evidence for the existence of these unusual graves is that around 1969, one of them, probably Burial A, was rediscovered and partially re-excavated by Lon Rayburn, then the owner of the western half of the site, who was in the process of unsystematically mining the remnants of the mound for anything Kizzia and Wood might have missed. I was working elsewhere at Crenshaw at the time and I saw it. Unfortunately I did not examine it in detail or--alas-photograph it. By then it was in miserable condition and I did not have the time to clean it up to the point where it could have been studied and photographed, assuming that I could have obtained permission to do so.

10. In his unpublished manuscript on the Crenshaw site (Wood 1963b), he calls it Burial 42. In his published summary of his 1962 work at Crenshaw (Wood 1963a: Figure 2), it is depicted as burials $7,8,9,11$, and 16 , all grouped in a pit which he outlined with a dotted line to indicate that the grave shaft was hard to see.

\section{References Cited}

Bell, Robert E.

1972 The Harlan Site, Ck-6: A Prehistoric Mound Center in Cherokee County, Eastern Oklahoma. Memoir No. 2.Oklahoma Anthropological Society, Norman.

1984 Arkansas Valley Caddoan: The Harlan Phase. In Prrehistory of Oklahoma, edited by Robert E. Bell, pp. 221-240. Academic Press, New York.

Belmont, John S.

1967 The Culture Sequence at the Greenhouse Site, Louisiana. Sutheastern Archaeological Conference Bulletin 6:27-34.

Brown, James A.

1979 Chamel Houses and Mortuary Crypts: Disposal of the Dead in the Middle Woodland Period. In Hopewell Archaeology, the Chillicothe Conference, edited by David S. Brose and N'omi Greber, pp. 211-219. Kent State University Press, Kent, Ohio.

1984 Arkansas Valley Caddo: The Spiro Phase. In Prehistory of Oklahoma, edited by Robert E. Bell, pp. 241-263, Academic Press, New York.

Champion, Timothy C.

1989 Introduction. In Cente and Periphery: Comparative Studies in Archaeology, edited by Timothy. C. Champion, pp. 1-21. Unwin Hyman, London.

Dincauze, Dena F. and Robert J. Hasenstab

1989 Explaining the Iroquois: Tribalization on a Prehistoric Periphery. In Centre and Periphery: Comparative Studies in Archaeology, edited by Timothy C. Champion. Unwin Hyman, London. 
Durham, James H. and Michael K. Davis

1975 Report on Burials Found at Crenshaw Mound "C". Bulletin of the Oklahoma Anthropological Society XXIII:1-90.

Ford, James A.

1951 Greenhouse: A Troyville-Coles Creek Period Site In Avoyelles Parish, Louisiarra. Anthropological Papers of the American Museum of Natural History, Vol. 44, Part 1 , New York.

Ford, James A. and Gordon R. Willey

1940 Crooks Site: A Markeville Period Burial Mound in La Salle Parish, Louisiana. Anthropological Study No. 3. Department of Conservation, Louisiana Geological Survey, New Orleans.

Fowler, Melvin L.

1991 Mound 72 and Early Mississippian at Cahokia. In New Perspectives on Cahokia: Views from the Periphery, edited by James B. Stoltman, pp. 1-28. Monographs in World Archaeology No. 2. Prehistory Press, Madison, Wisconsin.

Fulton, Robert and Clarence $\mathrm{H}$. Webb

1953 The Bellevue Mound: A Pre-Caddoan Site in Bossier Parish, Louisiana. Bulletin of the Texas Archeological Society 24:18-42.

Jeter, Marvin D., Jerome C. Rose, G. Ishmaet Williams, Jr., and Anna M. Harmon

1989 Archeology and Bioanthropology of the Lower Mississippi Valley and Trans-Mississippi South in Arkansas and Louisiana. Research Series No. 37. Arkansas Archeological Survey, Fayetteville.

Kelly, John

1991 The Evidence for Prehistoric Exchange and its Implications for the Development of Cahokia. In New Perspectives on Cahokia: Views from the Periphery, edited by James B. Stoltman, pp. 65-92. Monographs in World Archaeology No. 2. Prehistory Press, Madison, Wisconsin.

Lafferty, Robert/H. III

1994 Prehistorhc Exchange in the Lower Mississippi Valley. In Prehistoric Exchange Systems in North America, edited by Timothy G. Baugh and Jonathon E. Ericson, pp. 177-213, Plenum Press, New York.

Lemley, Harry J.

1936 Discoveries Indicating a Pre-Caddo Culture on the Red River in Arkansas. Bulletin of the Texas Archeological and Paleontological Society 8:25-55.

McClurkan, Burney B., Edward B. Jelks, and Harald P. Jensen

1980 Jonas Short and Coral Snake Mounds: A Comparison. Louisiana Archaeology 6:173-197.

Milanich, Jerald T. and Charles H. Fairbanks

1980 FloridaArchaeology. Academic Press, New York.

Newell, H. Perry and Alex D. Krieger

1949 The George C. Davis Site, Cherokee County, Texas. Memoir No. 5. Society for American Archaeology, Menasha, Wisconsin. 
Peregrine, Peter N.

1992 Mississippian Evolution: A World-System Perspective. Monographs in World Archaeology No. 9. Prehistory Press, Madison, Wisconsin.

Phillips, Philip

1970 Archaeological Survey in the Lower Yazoo Basin, Mississippi, 1949-1955. Papers of the Peabody Museum of Archaeology and Ethnology Volume 60. Harvard University, Cambridge, Massachusetts.

Rolingson, Martha Ann

1990 The Toltec Mounds Site: A Ceremonial Center in the Arkansas River Lowland. In The Mississippian Emergence, edited by Bruce D. Smith, pp. 27-49. Smithsonian Institution Press, Washington, D.C.

Rolingson, Martha Ann (editor)

1982 Emerging Patterns of Plum Bayou Culture:Preliminary Investigations of the Toltec Mounds Research Project. Research Series No. 18. Arkansas Archeological Survey, Fayetteville.

Sanderson, Stephen K. ( editor)

1995 Civilizations and World Systems: Studying World Historical Change. Altamira Press, Walnut Creek, California.

Schambach, Frank F.

1982 An Outline of Fourche Maline Culture in Southwest Arkansas. In Arkansas Archeology in Review, edited by Neal J. Trubowitz and Marvin D. Jeter, pp. 132-197. Research Series No. 15. Arkansas Archeological Survey, Fayetteville.

1991 Coles Creek Culture and the Trans-Mississippi South. Caddoan Archeology Newsletter, II (No. 3): 2-8.

1993 Some New Interpretations of Spiroan Culture History. In Archaeology of Eastern North America: Papers in Honor of Stephen Williams, edited by James B. Stoltman, pp.187-230. Archaeological Report No. 28. Mississippi Department of Archives and History, Jackson.

1995 A Probable Spiroan Entrepot in the Red River Valley in Northeast Texas. Caddoan Archeology Newsletter 6 (No. 1):9-25.

1996 Mounds, Embankments, and Ceremonialism in the Trans-Mississippi South. In Mounds, Embankments, and Ceremonialism in the Midsouth, edited by Robert C. Mainfort and Richard Walling, pp. 36-43. Research Series No. 46. Arkansas Archeological Survey, Fayetteville.

Schambach, Frank F. and Ann M. Early

1982 Southwest Arkansas. In A State Plan for the Conservation of Archeological Resources in Arkansas, edited by Hester A. Davis, pp. SW1-SW149. Research Series No. 21. Arkansas Archeological Survey, Fayetteville. 
Stewart-Abernathy, Judith C.

1982 Ceramic Studies at the Toltec Mounds Site: Basis for a Tentative Cultural Sequence. In Emerging Patterns of Plum Bayou Culture: Preliminary Investigations of the Toltec Mounds Research Project, edited by Martha Ann Rolingson, pp. 44-53. Research Series No. 18. Arkansas Archeological Survey, Fayetteville.

Story, Dee Ann, Janice A. Guy, Barbara A. Burnett, Martha Doty Freeman, Jerome C. Rose, D. Gentry Steele, Ben W. Olive, and Karl J. Reinhard.

1990 The Archeology and Bioarcheology of the Gulf Coastal Plain. 2 Vols. Research Series No. 38. Arkansas Archeological Survey, Fayettevllle.

Toth, Alan

1988 Early Markeville Phases in the Lower Mississippi Valley: A Study of Culture Contact Dynamics. Archaeological Reports No. 21. Mlssissippi Department of Archives and History, Jackson.

Wallerstein, Emmanuel

1974 The Modern World-System: Capitalist Agriculture and the Origins of the European World-Economy in the Sixteenth Century. Academic Press, New York.

Webb, Clarence H.

1984 The Bellevue Focus: A Markeville-Troyville Manifestation Northwestern Louisiana. Louisiana Archaeology 9:251-274.

Webb, Clarence H. and RaIph R. McKinney

1975 Mounds Plantation (16CD12), Caddo Parish, Louisiana. Louisiana Archaeology 2:39-127.

Williams, Stephen and Jeffrey P. Brain

1983 Excavations at the Lake George Site, Yazoo County, Mississippi, 1958-1960. Papers of the Peabody Museum of Archaeology and Ethnology, Volume 74. Harvard University Press, Cambridge, Massachusetts.

Wood, W. Raymond

1963a A Preliminary Report on the 1962 Excavations at the Crnshaw Site, 3MI6. In Arkansas Archeology, 1962: An Annual Report on Archeological Research, Investigation, Activities and Progress in the State of Arkansas, edited by Charles R. McGimsey III, pp. 1-14, Special Publication of the Arkansas Archeological Society, Fayetteville.

1963b The Crenshaw Site; A Coles Creek and Caddoan Mound Group in Miller County, Arkansas. Unpublished manuscript on file at the University of Arkansas Museum, Fayetteville. 